\title{
HYGIENIC STUDIES OF FARMING VILLAGES IN TOCHIGI PREFECTURE III
}

\section{REPORT 2. GROUP MEDICAL EXAMINATION OF MOTEGI TOWN ON THE BLOOD PRESSURE, ECG FINDINGS AND THE RESULTS OF URINE EXAMINATION}

\author{
Isamu OKADA, Hiroshi TATE and Yoshikazu MIURA*
}

The previous report treated of the cephalic and facial findings, physique, bodily type, percussive and auscultatory findings and cutaneous findings of the inhabitants living in the Shimogo and Kamisugamata Sections of Motegi Town. This report treats of the blood pressure, ECG findings and the results of urine examination.

\section{TIME AND SUBJECT OF INVESTIGATION}

As in the previous report ${ }^{1}$, we made the same investigation of the 53 persons in the Shimogo Section on the 14 th of September, 1976 and of the 54 persons in the Kamisugamata Section on the 16th and 17 th of April, 1977 at the public hall of each section. The number of persons by age-group, that of examinees and the rate of examination are shown in Table 1 .

Table 1 Persons by Age-group, Examinees and Rate of Examination in Shimogo and Kamisugamata Sections

\begin{tabular}{|c|c|c|c|c|c|c|c|}
\hline \multicolumn{2}{|c|}{ Section } & \multicolumn{3}{|c|}{ Shimogo } & \multicolumn{3}{|c|}{$\begin{array}{l}\text { Kamisugamata (containing part } \\
\text { of Shimogo Section) }\end{array}$} \\
\hline $\begin{array}{c}\text { Age- } \\
\text { Group }\end{array}$ & Sex & $\begin{array}{c}\text { Population } \\
\text { (s. 51) }\end{array}$ & $\begin{array}{c}\text { Examinees } \\
\text { (s. 51.9) }\end{array}$ & $\begin{array}{c}\text { Rate of } \\
\text { Examination }\end{array}$ & $\begin{array}{l}\text { Population } \\
\text { (s. 52) }\end{array}$ & $\begin{array}{c}\text { Examinees } \\
\text { (s. 52.4) }\end{array}$ & $\begin{array}{c}\text { Rate of } \\
\text { Examina- } \\
\text { tion }\end{array}$ \\
\hline $70 \sim$ & $\begin{array}{c}\text { Male } \\
\text { Female }\end{array}$ & $\begin{array}{l}6 \\
6\end{array}$ & $\begin{array}{l}4 \\
4\end{array}$ & $\begin{array}{l}66.7 \\
66.7\end{array}$ & $\begin{array}{l}7 \\
8\end{array}$ & $\begin{array}{l}4 \\
3\end{array}$ & $\begin{array}{l}57.1 \\
37.5\end{array}$ \\
\hline $60 \sim$ & $\begin{array}{c}\text { Male } \\
\text { Female }\end{array}$ & $\begin{array}{l}7 \\
9\end{array}$ & $\begin{array}{l}2 \\
9\end{array}$ & $\begin{array}{r}28.6 \\
100.0\end{array}$ & $\begin{array}{r}9 \\
11\end{array}$ & $\begin{array}{r}5 \\
16\end{array}$ & $\begin{array}{r}55.6 \\
100.0\end{array}$ \\
\hline $50 \sim$ & $\begin{array}{c}\text { Male } \\
\text { Female }\end{array}$ & $\begin{array}{l}9 \\
9\end{array}$ & $\begin{array}{l}9 \\
9\end{array}$ & $\begin{array}{l}100.0 \\
100.0\end{array}$ & $\begin{array}{r}9 \\
11\end{array}$ & $\begin{array}{r}5 \\
14\end{array}$ & $\begin{array}{r}55.6 \\
100.0\end{array}$ \\
\hline $40 \sim$ & $\begin{array}{c}\text { Male } \\
\text { Female }\end{array}$ & $\begin{array}{l}10 \\
10\end{array}$ & $\begin{array}{l}5 \\
5\end{array}$ & $\begin{array}{l}50.0 \\
50.0\end{array}$ & $\begin{array}{l}16 \\
11\end{array}$ & $\begin{array}{l}4 \\
3\end{array}$ & $\begin{array}{l}25.0 \\
27.3\end{array}$ \\
\hline $30 \sim$ & $\begin{array}{c}\text { Male } \\
\text { Female }\end{array}$ & $\begin{array}{l}7 \\
5\end{array}$ & $\begin{array}{l}3 \\
1\end{array}$ & $\begin{array}{l}42.9 \\
20.0\end{array}$ & $\begin{array}{l}4 \\
9\end{array}$ & $\begin{array}{l}0 \\
0\end{array}$ & $\begin{array}{l}0.0 \\
0.0\end{array}$ \\
\hline $20 \sim$ & $\begin{array}{c}\text { Male } \\
\text { Female }\end{array}$ & $\begin{array}{l}10 \\
10\end{array}$ & $\begin{array}{l}1 \\
1\end{array}$ & $\begin{array}{l}10.0 \\
10.0\end{array}$ & $\begin{array}{r}8 \\
11\end{array}$ & $\begin{array}{l}0 \\
0\end{array}$ & $\begin{array}{l}0.0 \\
0.0\end{array}$ \\
\hline $10 \sim$ & $\begin{array}{c}\text { Male } \\
\text { Female }\end{array}$ & $\begin{array}{l}3 \\
5\end{array}$ & $\begin{array}{l}0 \\
0\end{array}$ & $\begin{array}{l}0.0 \\
0.0\end{array}$ & $\begin{array}{l}15 \\
17\end{array}$ & $\begin{array}{l}0 \\
0\end{array}$ & $\begin{array}{l}0.0 \\
0.0\end{array}$ \\
\hline $0 \sim$ & $\begin{array}{c}\text { Male } \\
\text { Female }\end{array}$ & $\begin{array}{r}7 \\
12\end{array}$ & $\begin{array}{l}0 \\
0\end{array}$ & $\begin{array}{l}0.0 \\
0.0\end{array}$ & $\begin{array}{r}11 \\
7\end{array}$ & $\begin{array}{l}0 \\
0\end{array}$ & $\begin{array}{l}0.0 \\
0.0\end{array}$ \\
\hline Total & $\begin{array}{c}\text { Male } \\
\text { Female }\end{array}$ & $\begin{array}{l}60 \\
67\end{array}$ & $\begin{array}{l}24 \\
29\end{array}$ & $\begin{array}{l}40.0 \\
43.3\end{array}$ & $\begin{array}{l}79 \\
85\end{array}$ & $\begin{array}{l}18 \\
36\end{array}$ & $\begin{array}{l}22.8 \\
42.4\end{array}$ \\
\hline
\end{tabular}

* Department of Hygiene, Dokkyo University School of Medicine 
We measured blood pressure at the right upper arm by auscultatory method with a Riva-Rocci sphygmomanometer in a sitting position, adopting Swan point five as minimum blood pressure. We took electrocardiograms with a DU-3S electrocardiograph manufactured by FUKUDA DENSHI CO., LTD., and we made an examination of albuminuria and glycosuria by a Combistix manufactured by MILES-SANKYO CO., LTD. and of urobilinogen by a Urobilistix manufactured by the same company.

\section{RESULTS}

\section{Blood pressure}

As is shown in Fig. 1, the maximum blood pressure of both the males and females in the Shimogo Section is about $130-139 \mathrm{mmHg}$, of whom 5 males $(20.8 \%)$ and 14 females $(48.3 \%)$ are above $150 \mathrm{mmHg}$, and so more females are sufferers from high blood pressure. Nevertheless, no statistically significant difference can be seen between the males and the females of over 40 years $\left(\mathrm{X}^{2}=3.44\right)$.

As is shown in Fig. 2, the minimum blood pressure of most males is about $80-89 \mathrm{mmHg}$, while that of most females is about $70-79 \mathrm{mmHg}$, and no statistically significant difference can be seen between the sexes. The minimum blood pressure of 6 males $(25.0 \%)$ and as many females $(20.7 \%)$ is above $90 \mathrm{mmHg}$.

As is shown in Table 2, the average and the standard deviation of maximum and minimum blood pressure of 20 males of over 40 years are $137.3 \pm 18.7 \mathrm{mmHg}$ and $83 \pm 11.6 \mathrm{mmHg}$ respectively and those of 27 females of over 40 years are $151.4 \pm 28.0 \mathrm{mmHg}$ and $79.9 \pm 12.8 \mathrm{mmHg}$. No statistically significant difference can be seen between the sections and sexes.

As is shown in Fig. 3, the maximum blood pressure of the males and females in the Kamisugamata Section is mostly about $130-139 \mathrm{mmHg}$ and about $140-149 \mathrm{mmHg}$ respectively.

The maximum blood pressure of 5 males $(27.8 \%)$ and 10 females $(28.6 \%)$ is above $150 \mathrm{mmHg}$, which is about the same rate, and no statistically significant difference can be seen between the sexes.

As is shown in Fig. 4, the minimum blood pressure of the males and females in the section is mostly about $80-89$ mmHg. The minimum blood pressure of 4 males $(22.2 \%)$ and 8 females $(22.9 \%)$ is above $90 \mathrm{mmHg}$, which is about the same rate, and no statistically significant difference can be seen between the sexes.

As is shown in Table 2, the average and the standard deviation of maximum and minimum blood pressure of 18 males of over 40 years are $137.1 \pm 21.2 \mathrm{mmHg}$ and $81.4 \pm 9.9 \mathrm{mmHg}$ respectively and those of 35 females of over 40 years are $140.7 \pm 18.1 \mathrm{mmHg}$ and $81.1 \pm 11.3 \mathrm{mmHg}$. And no statistically significant difference can be seen between the sexes and sections.

Table 2 The Average Value of Blood Pressure of the persons of over 40 years in both Sections

\begin{tabular}{c|c|c|c|c|c}
\hline & Sex & $\begin{array}{c}\text { Number of } \\
\text { Persons }\end{array}$ & $\begin{array}{c}\text { Shimogo } \\
\text { (mmHg) }\end{array}$ & $\begin{array}{c}\text { Number of } \\
\text { Persons }\end{array}$ & $\begin{array}{c}\text { Kamisugamata } \\
\text { (mmHg) }\end{array}$ \\
\hline \multirow{2}{*}{ Maximum } & Male & 20 & $137.3 \pm 18.7$ & 18 & $137.1 \pm 21.2$ \\
& Female & 27 & $151.4 \pm 28.0$ & 35 & $140.7 \pm 18.1$ \\
\hline \multirow{2}{*}{ Minimum } & Male & 20 & $83.0 \pm 11.6$ & 18 & $81.4 \pm 9.9$ \\
& Female & 27 & $79.9 \pm 12.8$ & 35 & $81.1 \pm 11.3$
\end{tabular}




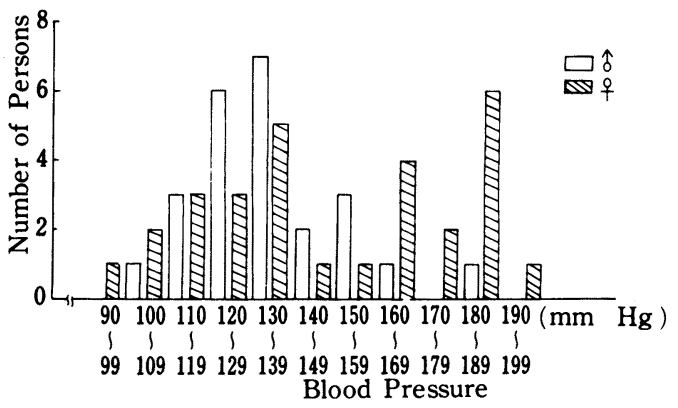

Fig. 1 Maximum Blood Pressure in Shimogo Section (September, 1976)

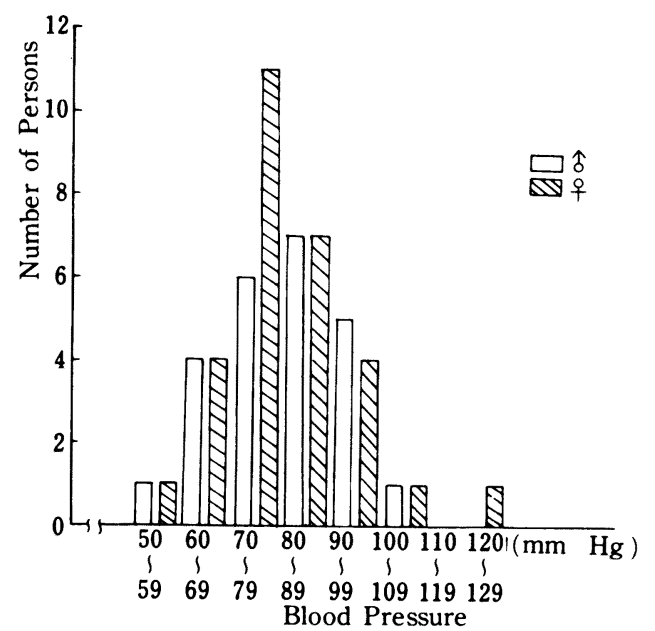

Fig. 2 Minimum Blood Pressure in Shimogo Section (September, 1976)

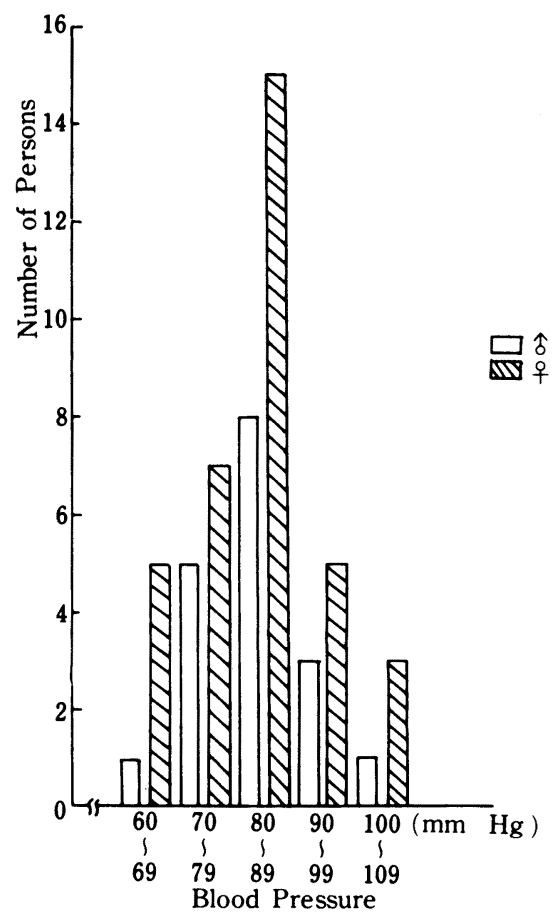

Fig. 4 Minimum Blood Pressure in Kamisugamata Section (April, 1977) 


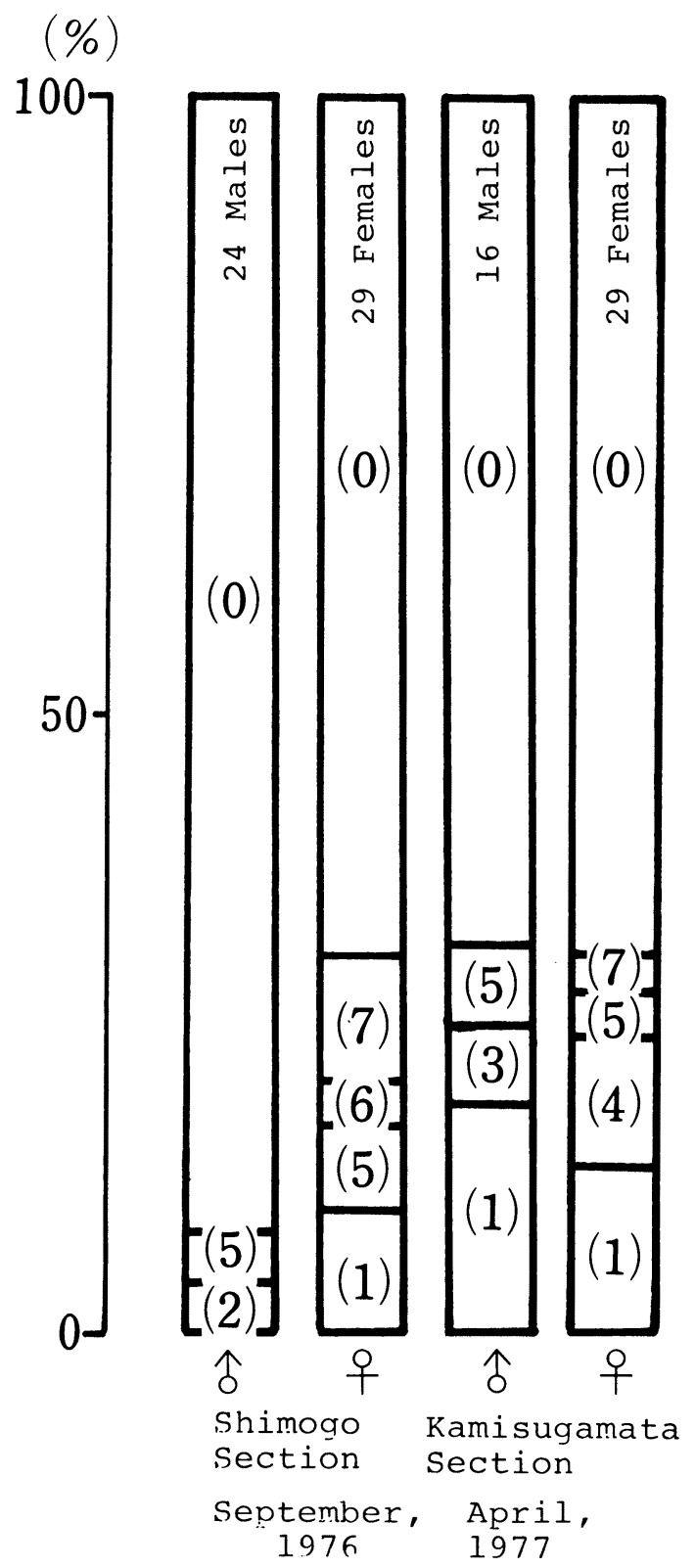

Fig. 5 ECG Findings

Of the persons of over 40 years in both sections, $51.9 \%$ of the females in the former section and $28.6 \%$ of the females in the latter section have the maximum blood pressure of over $150 \mathrm{mmHg}$, and this difference is statistically significant at the level of $5.0 \%\left(\mathrm{X}^{2}=3.84\right)$, while the difference of the males in both sections is statistically insignificant.

As to the average blood pressure of the persons of over 40 years, no statistically significant difference is, after all, seen between the sections and sexes.

The Shimogo Section has more females suffering from blood pressure of higher than $150 \mathrm{mmHg}$ with a statistically significant difference at the level of $5.0 \%$.

In 1962, WHO stated that hypertension was maximum blood pressure over $160 \mathrm{mmHg}$ and minimum blood pressure 
over $95 \mathrm{mmHg}$, that border blood pressure was maximum from $140 \mathrm{mmHg}$ to $160 \mathrm{mmHg}$ and minimum from $90 \mathrm{mmHg}$ to $95 \mathrm{mmHg}$ and that normal blood pressure was maximum under $140 \mathrm{mmHg}$ and minimum under $90 \mathrm{mmHg}$.

Recently, this classification has widely been adopted in Japan. According to this division, as is shown in Table 3 , and Table 4, 2 males (8.3\%) and 2 females $(6.9 \%)$ in the former section, and 2 males $(11.1 \%)$ and 3 females $(8.6 \%)$ in the latter section are sufferers from hypertension.

Table 3 Classification of Blood Pressure by WHO September, 1976 (Shimogo Section)

\begin{tabular}{|c|c|c|c|c|c|c|c|c|c|}
\hline \multicolumn{5}{|c|}{ Maximum Blood Pressure } & & & \multicolumn{3}{|c|}{ Maximum Blood Pressure } \\
\hline & Male & $\begin{array}{c}\text { under } \\
140 \mathrm{mmHg}\end{array}$ & $\begin{array}{c}\text { over } \\
140 \mathrm{mmHg} \\
\text { under } \\
160 \mathrm{mmHg}\end{array}$ & $\begin{array}{c}\text { over } \\
160 \mathrm{mmHg}\end{array}$ & & male & $\begin{array}{c}\text { under } \\
140 \mathrm{mmHg}\end{array}$ & $\begin{array}{c}\text { over } \\
140 \mathrm{mmHg} \\
\text { under } \\
160 \mathrm{mmHg}\end{array}$ & $\begin{array}{c}\text { over } \\
160 \mathrm{mmHg}\end{array}$ \\
\hline 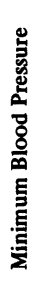 & $\begin{array}{c}\text { under } \\
90 \mathrm{mmHg} \\
\text { over } \\
90 \mathrm{mmHg} \\
\text { under } \\
90 \mathrm{mmHg} \\
\text { over } \\
95 \mathrm{mmHg}\end{array}$ & $\begin{array}{c}16 \\
(66.7 \%) \\
1\end{array}$ & $\begin{array}{c}2 \\
1 \\
(4.2 \%) \\
2\end{array}$ & $\begin{array}{c}0 \\
\\
2 \\
(8.3 \%)\end{array}$ & 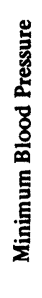 & $\begin{array}{c}\text { under } \\
90 \mathrm{mmHg} \\
\text { over } \\
90 \mathrm{mmHg} \\
\text { under } \\
95 \mathrm{mmHg} \\
\text { over } \\
95 \mathrm{mmHg}\end{array}$ & $\begin{array}{c}14 \\
(48.3 \%) \\
0\end{array}$ & $\begin{array}{c}0 \\
(0 \%) \\
0\end{array}$ & $\begin{array}{c}2 \\
(6.9 \%)\end{array}$ \\
\hline
\end{tabular}

Table 4 Classification of Blood Pressure by WHO April, 1977 (Kamisugamata Section)

\begin{tabular}{|c|c|c|c|c|c|c|c|c|c|}
\hline & \multicolumn{4}{|c|}{ Maximum Blood Pressure } & & & \multicolumn{3}{|c|}{ Maximum Blood Pressure } \\
\hline & Male & $\begin{array}{c}\text { under } \\
140 \mathrm{mmHg}\end{array}$ & $\begin{array}{c}\text { over } \\
140 \mathrm{mmHg} \\
\text { under } \\
160 \mathrm{mmHg}\end{array}$ & $\begin{array}{c}\text { over } \\
160 \mathrm{mmHg}\end{array}$ & & male & $\begin{array}{c}\text { under } \\
140 \mathrm{mmHg}\end{array}$ & $\begin{array}{c}\text { over } \\
140 \mathrm{mmHg} \\
\text { under } \\
160 \mathrm{mmHg}\end{array}$ & $\begin{array}{c}\text { over } \\
160 \mathrm{mmHg}\end{array}$ \\
\hline 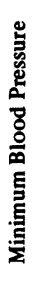 & $\begin{array}{c}\text { under } \\
90 \mathrm{mmHg} \\
\text { over } \\
90 \mathrm{mmHg} \\
\text { under } \\
95 \mathrm{mmHg} \\
\text { over } \\
95 \mathrm{mmHg}\end{array}$ & $\begin{array}{c}11 \\
(61.1 \%) \\
0\end{array}$ & $\begin{array}{c}2 \\
1 \\
(5.6 \%) \\
0\end{array}$ & $\begin{array}{c}1 \\
1 \\
\\
\\
2 \\
(11.1 \%)\end{array}$ & 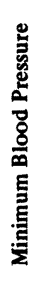 & $\begin{array}{c}\text { under } \\
90 \mathrm{mmHg} \\
\text { over } \\
90 \mathrm{mmHg} \\
\text { under } \\
95 \mathrm{mmHg} \\
\text { over } \\
95 \mathrm{mmHg}\end{array}$ & $\begin{array}{c}14 \\
(40 \%) \\
1\end{array}$ & $\begin{array}{c}12 \\
1 \\
(2.9 \%)\end{array}$ & $\begin{array}{c}3 \\
(8.6 \%)\end{array}$ \\
\hline
\end{tabular}

\section{ECG}

As is shown in Table 5 and Fig. 5, all the examinees (24 males and 29 females) in the Shimogo Section took ECG's in September, 1976, while 16 males (88.8\%), and 29 females (80.5\%) in the Kamisugamata Section did in April, 1977.

The older is age, the more are ECG findings, which are seen in $8.3 \%$ of the males and $31.0 \%$ of the females in the Shimogo Section and in $31.0 \%$ of both the males and females in the Kamisugamata Section.

By disease, 10 cases $(10.2 \%)$ of sinus bradycardia stand first in number, 5 cases $(5.1 \%)$ of ventricular premature beats stand second and findings are seen in 25 cases $(25.5 \%)$.

When the rate of finding-holders, male and female, of over 40 years in the former section is compared with that of the latter section, no statistically significant difference can be seen between the sections and the sexes of each age-group.

Nevertheless, the rate of finding-holders in the latter section is higher than that of the former section in both the males and females of each age-group except females in their sixties and seventies. This may be due to fatigue in the busy farming season. 


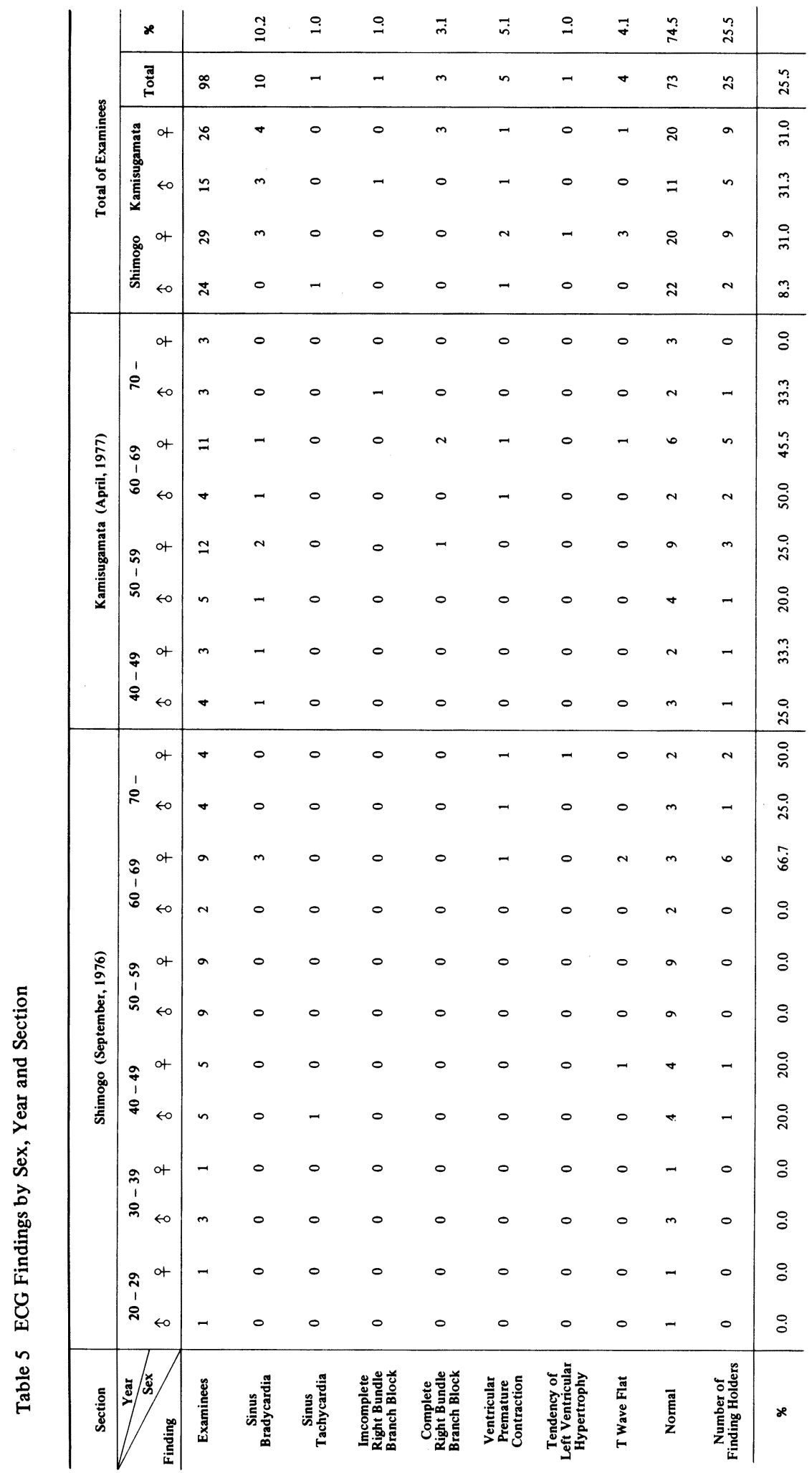




\section{Results of urine examination}

In the Shimogo Section (Sept. in 1976) nobody was suffering from abnormal urobilinogen reaction of urine, as is shown in Table 6. 2 males and no females were suffering from albuminuria, and 2 males (8.7\%) were suffering from glycosuria.

In the Kamisugamata Section (April in 1977) as many as 2 males (11.1\%) and 12 females (35.3\%) were suffereing from abnormality (increase) of urobilinogen reaction of urine.

As is shown in Table 6, this seems to be due to fatigue in the busy farming season, as in the case of ECG.

As to albuminuria, 2 males $(11.1 \%)$ and 4 females (11.8\%) were light positive and 1 female was moderate positive. As to glycosuria, 1 female $(2.9 \%)$ was suffering from it.

As compared with the former section, the latter section has more males and females positive in urobilinogen reaction, and the difference is statistically significant at the level of $1.0 \%$ by $\mathrm{X}^{2}$-test $\left(\mathrm{X}^{2}=14.84\right)$ in the case of the females, though insignificant in the case of the males.

As to albuminuria, more sufferers from it are found in the latter section, and the difference is significant at the level of $5.0 \%$ by $\mathrm{X}^{2}$-test $\left(\mathrm{X}^{2}=3.58\right)$ in the case of the females, though insignificant in the case of the males. 


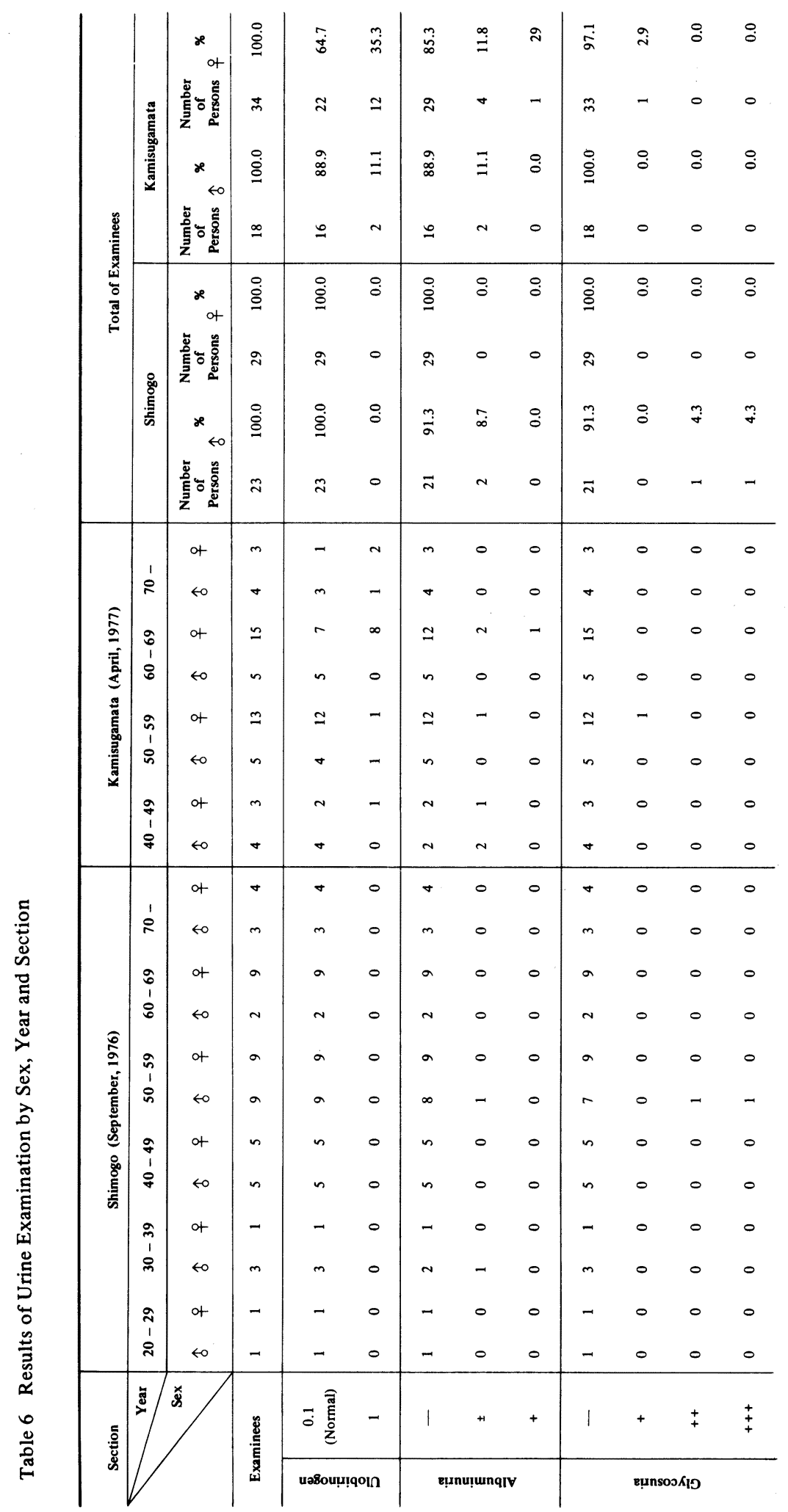




\section{SUMMARY AND DISCUSSION}

It has long been suggested that the law of Poiseuille ${ }^{2)}$ ) is related to blood pressure. Clinically speaking, the following seem to be factors ${ }^{4) 5}$ in the development of hypertension - a renal factor concerned with renin-angiotensin system, an endocrine factor implicated in catecholamines or aldosterone and a neurogenic factor.

Hygienically ${ }^{6}$ it is a matter of common knowledge that heredity ${ }^{7)}$, season ${ }^{8)}$ or temperature ${ }^{8)}$, food ${ }^{9)}$, especially salt ${ }^{10)}$ intake, and labour ${ }^{1112)}$, etc. may be factors.

In Japan, maximum blood pressure of higher than $150 \mathrm{mmHg}$ has been considered to be hypertension ${ }^{13)}$ and that of lower than $100 \mathrm{mmHg}$ to be hypotension ${ }^{13}$

At present, clinicians commonly regard maximum blood pressure of higher than $140 \mathrm{mmHg}$ and minimum blood pressure of higher than $90 \mathrm{mmHg}$ in the case of young people, and maximum blood pressure of higher than $150 \mathrm{mmHg}$ and minimum blood pressure of higher than $90 \mathrm{mmHg}$ in the case of elderly people as hypertension, and except in case of life and death, they observe the patients for a certain period with no antihypertensive drugs. ${ }^{14)}{ }^{15}$.

Now that our national physique has recently improved, the value of blood pressure in healthy young, mature and elderly people has come to be divided according to the classification of WHO.

As to the average value of blood pressure of people of over 40 years in the present investigation, no statistically significant difference can be seen between the sections and sexes. However, maximum blood pressure of higher than $150 \mathrm{mmHg}$ was observed in more females in the former section statistically at the level of $5.0 \%$. This seemed to be due to their overwork in the busy farming season, for in the former section their blood pressure was measured in September, 1976 - the relatively slack season and in the latter section in April, 1977 - the busy farming season.

It is possible that their blood pressure was lowered by the effect of temperature and, as Nishikawa ${ }^{11)}$ and Takahashi ${ }^{12)}$ pointed out, overwork.

As to ECG findings, $3.3 \%$ of the males and $31.0 \%$ of the females in the former section are sufferers, while $31.0 \%$ of both the males and the females in the latter section are sufferers. As mentioned above, ECG findings are seen in more males in the latter section, though the difference is statistically insignificant. This may be due to their overwork in the busy farming season. The rate of finding-holders is higher than that of Nango Village (males $12.8 \%$, females $12.7 \%{ }^{16)}{ }^{17}$ ) in Fukushima Prefecture, which was investigated by us in June, 1976, and this rate is near to the rate of $20.0 \%$ of the males and $36.2 \%$ of the females in the whole prefecture of Nagano, which was investigated by the Prefectural General Health Center ${ }^{18)}$.

According to the results of urine examination, the positive rate of urobilinogen in the latter section is higher than that of the former section, which may, as mentioned above, be due to fatigue in the busy farming season.

It is of great interest that this is in accord with the lower value of blood pressure and higher rate of ECG findings of the people in the latter section, where their fatigue of farm work seriously affects their health.

\section{CONCLUSIONS}

We made investigations of the 53 persons in the Shimogo Section on the 14th of September, 1976, and of the 54 persons in the Kamisugamata Section on the 16 th and 17 th of April, 1977, and came to the following conclusions.

1) The average and the standard deviation of maximum and minimum blood pressure of the males of over 40 years in the Shimogo Section are $137.3 \pm 18.7 \mathrm{mmHg}$ and $83.0 \pm 11.6 \mathrm{mmHg}$, and those of the females in the same section are $151.4 \pm 28.0 \mathrm{mmHg}$ and $79.9 \pm 12.8 \mathrm{mmHg}$, while those of the males of over 40 years in the Kamisugamata Section are $137.1 \pm 21.2 \mathrm{mmHg}$ and $81.4 \pm 9.9 \mathrm{mmHg}$, and those of the females in the same section are $140.7 \pm 18.1 \mathrm{mmHg}$ and 81.3 $\pm 11.3 \mathrm{mmHg}$. No statistically significant difference can be seen between the sections and sexes. The former section has more females suffering from blood pressure of higher than $150 \mathrm{mmHg}$ with s statistically significant difference at the level of $5.0 \%$.

2) ECG findings can be seen in $8.3 \%$ of the males and $31.0 \%$ of the females in the former section and in $31.0 \%$ of both the males and females in the latter section. The males in the latter section have more findings than those of the former 
section, though the difference is statistically insignificant. This may be due to their overwork in the busy farming season.

3) As to positive reaction of urobilinogen in urine (an abnormal increase), nobody is suffering from it in the former section, while as many as 2 males $(11.1 \%$ ) and 12 females (35.3\%) are suffering from it in the latter section. This seems to be due to their fatigue in the busy farming season.

As to albuminuria, 2 males and 5 females in the latter section are suffering from it.

As to glycosuria, 2 males in the former section and 1 female in the latter section are suffering from it.

The point of this paper was reported at the 26 th congress of Japanese Association of Rural Medicine ${ }^{19}{ }^{20}$ (at Nagoya City, October 21, 1977).

\section{REFERENCES}

1) Isamu OKADA and Hiroshi TATE: Hygienic Studies of Farming Villages in Tochigi Prefecture (I) General Survey of Tochigi Prefecture and the Relationship of Alienated Areas to Population Index and Others, Human Ecology and Race Hygiene, 42, 302 (1976)

2) Naosaburo YOSHII: RINSHOSEIRIGAKU, NAGAI SHOTEN, Osaka, second ed., p287 (1955)

3) Toyozo AIZAWA and Tsuneo HASEGAWA: Hypertension and Hypotension, HOOMEIDO, Tokyo, third ed., p1 (1977)

4) Yoshiaki MASUYAMA: KOKETSUATU NO SHINDAN TO CHIRYO NO KOTSU, NANKODO, Tokyo, third ed., p17 (1971)

5) Yoshiaki MASUYAMA: Hypertension, Japan Medical Journal, No. 2812, p3 (1978)

6) Isamu OKADA: Hygienic Studies of Japanese Farming Villages IX, Functional Survey of the Blood Pressure of Aged People, ACTA SCHOLAE MEDICINALIS IN GIFU, Vol, 11, 32 (1963)

7) Sadanobu MIYAO: Arterial Hypertension (Heredity and Consitution), Japanese Circulation Journal, 17, 140 (1953)

8) Yuhei MEGURO: The Blood Pressure Level and the Influence of Living Conditions on it in an Agricultural Village in Miyagi Prefecture, Japan, Human Ecology and Race Hygiene, 27, 339 (1961)

9) Eiko OHBA: Studies on the Blood Pressure Level of Inhabitants in a Farm Village of the Tohoku District and the Analysis of its Related Factors, Human Ecology and Race Hygiene, 25, 140 (1959)

10) Naosuke SASAKI, Toju TAKEDA, Sho FUKUSHI, Teisho MITSUHASHI, Tsuneaki HIJIKATA, Masanori FUKUSHI, and Ryuichi ISHIYAMA: On the Nutritional Factors Related to the Geographical Difference in the Death Rate from Apoplexy in Japan, J.J.P.H., 7, 1137 (1960)

11) Mitsuhiko NISHIKAWA: Studies in Public Health in Sado-Island, Part II. On Anaemia and Cardiovascular System of Inhabitants, Human Ecology and Race Hygiene, 23, 179 (1957)

12) Eiji TAKAHASHI, Katsuo KATO, Yoshiaki KAWAKAMI, Kozo ISHIGURO, Shoji KANETA, Yotaro SUZUKI, and Tsuneari SUGAWARA: Does the Farming Labor in the Busy Season Influence the Blood Pressure Level of Farmers? J.J.P.H., 7, 140 (1960)

13) Yoshio KATO: IJYOKETSUATSU, IGAKUSHOIN, Tokyo, first ed., p9 (1954)

14) Yoshiaki MASUYAMA: KOKETSUATSU NO SHINDAN TO CHIRYO NO KOTSU, NANKODO, Tokyo, third ed,, p17 (1971)

15) Toyozo AIZAWA and Tsuneo HASEGAWA: Hypertension and Hypotension, HOOMEIDO, Tokyo, third ed., p27 (1977)

16) Isamu OKADA: Sports Injury from the Viewpoint of Internal Medicine, Journal of Physical Education, Vol 4, 65 (1977)

17) Yoshikazu MIURA, Isamu OKADA, Hiroshi TATE, Toki WATANABE and Jiro WATANABE: Hygienic Studies of Remote Farming Areas (Report 2), The Results of a Mass Examination of School Children and Adults in Nango Village, Fukushima Pref., Jap. J. Hyg.,Vol 32, 313 (1977)

18) Nagano General Health Center: The Results of Examination at Nakano City (compared with the whole prefecture), 
$330(24)$

Pamphlet of Nagano General Health Center, p5 (1976)

19) Isamu OKADA, Hiroshi TATE, Yoshikazu MIURA and Yoko TAGUCHI: Hygienic Studies of Farming Villages in Tochigi Prefecture, Report 5 The Results of a Mass Examination, J.J.R.M., 26, 729 (1978)

20) Isamu OKADA, Hiroshi TATE, Yoshikazu MIURA and Yoko TAGUCHI: Hygienic Studies of Farming Villages in Tochigi Prefecture, Report 5 The Results of a Mass Examination, J.J.R.M., 26, 423 (1977) 
〈要 約〉

農 村 (栃木県) の衛生学的研究 (III)

第 2 報 茂木町の集団検診一血圧，心電図所見並びに検尿成績について

岡田 勇, 楯 博, 三浦善憲

農村(栃木県)の衛生学的研究( I )，栃木県及び過疎 町村の一般的観察成績ならびに人口指数その他につい て，民族衛生第42巻(1976)に報告し，農村(栃木県)の 同研究( II ), 農作物ならびに青果物収穫量と市町村別 訂正死亡率その他との関係について，さらに農村( 栃 木県) の同研究( III) 第 1 報茂木町の集団検診, 頭部, 顔面所見及び打聴診所見 (Hygienic Studies of Farming Villages in Tochigi Prefecture (III), Report I, Group medical Examination on the Cephalic, Facial, Percussive and Ausculatory Finding）と題し,茂木町下郷ならびに上菅又地区住民の頭部 顔面所見，体位，体型，打聴診所見，ならびに皮膚所 見について同誌に報告した。本報では，引き続いて， 前地区住民の血圧, 心電図所見, 検尿成績について述 べる。

1976年 9 月下郷地区 53 名, 1977 年 4 月上菅又地区 54

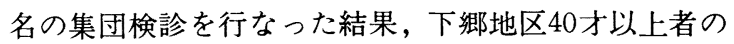
平均血圧は, 男: 最高血圧 $137.3 \pm 18.7 \mathrm{~mm} H$, 最低血圧 83.0 $\pm 11.6 \mathrm{~mm} H \mathrm{~g}$, 女 : 最高血圧 $151.4 \pm 28.0 \mathrm{mmHg}$, 最低血圧 $79.9 \pm 12.8 \mathrm{mmHg}$ で, 上菅又地区40才以上のそれは,男 : 最高血圧 $137.1 \pm 21.2 \mathrm{mmHg}$, 最低血圧 $81.4 \pm 9.9 \mathrm{~mm} \mathrm{Hg}$, 女：最高血圧 $140.7 \pm 18.1 \mathrm{mmHg}$, 最低血圧 $81.3 \pm 11.3 \mathrm{mmHg}$ であった。女の最高血圧 $150 \mathrm{mmHg}$ 以上の者は, 統計学的 に $5 \%$ 以下の危険率で有意差をもって下郷地区に多か った。

心電図所見では，下郷地区の男 $8.3 \%$,女 $31.0 \%$ に, 上菅又地区の男女とも $31.0 \%$ に所見がみられ，農繁期 労働が影響しているものと考えられる。

検尿成績でも，下郷地区では，ウロビリノーゲン陽 性が，1名もなく，上菅又地区の男 $11.1 \%$ ，女 $35.3 \%$ にウロビリノーゲン陽性がみられ，心電図所見と同じ ように農繁期労働による影響がみられた。

*独協科大学衛生学教室（主任: 岡田 勇教授

受付：昭和 53 年 8 月 8 日 